Gut, 1966, 7, 680

\title{
ABO blood groups in gastric bleeding
}

\author{
L. HORWICH, D. A. P. EVANS, R. B. MCCONNELl, AND W. T. A. DONOHOE \\ From the Department of Medicine, University of Liverpool
}

EDITORIAL SYNOPSIS This paper confirms previous studies showing the increased risk of bleeding associated with blood group $\mathrm{O}$. There is an indication that this may also be true for acute perforation and indeed the relationship may be with the severity of the ulcer disease.

In a previous paper (Horwich and Evans, 1966) a relationship was shown between the loss of gastric mucosal cells in 160 volunteer subjects and their $\mathrm{ABO}$ blood groups and $\mathrm{ABH}$ secretor status. Aspirin enhanced the loss from the gastric mucosa, and it was postulated that clinical overt bleeding from the gastric mucosa, whether aspirin-induced or not, may also be related to the $\mathrm{ABO}$ blood groups and secretor status. The present investigation concerns this problem, and it was also thought to be of value to extend the investigation to include subjects with duodenal ulcer because of the reported association with blood group $O$ (Aird, Bentall, Mehigan, and Roberts, 1954) and with ABH non-secretion (Clarke, Edwards, Haddock, Howel-Evans, McConnell, and Sheppard, 1956). While the work was in progress, Langman and Doll (1965) reported an increased frequency of group $\mathbf{O}$ in gastric and duodenal ulcer subjects who had bled and an increased incidence of non-secretors in those who had undergone operation.

\section{METHODS}

Two separate series of patients were ascertained.

SUBJECTS WITH HAEMATEMESIS AND MELAENA The first series was ascertained by collecting the case records of patients who had been admitted to six hospitals in the Liverpool area with haematemesis and melaena. To obtain a large series of in-patients a list of case records was prepared by examining hospital and ward admission registers and the diagnostic indices for haematemesis and melaena. The case sheets were scrutinized for evidence of bleeding and were included in the series only if the following criteria were satisfied:-Substantial haematemesis or frank melaena witnessed by a member of the hospital medical staff or senior nursing staff; history of haematemesis or melaena together with a very low or falling haemoglobin level and strongly positive faecal occult blood test; acute clinical 'shock', requiring blood transfusion and strongly positive occult blood test.

Case records were examined for a history of salicylate ingestion during the 48 hours before the onset of bleeding and recorded at the time of admission. Details were abstracted of a barium meal examination carried out within two weeks after the bleeding episode. Where the radiologist gave a firm opinion on the presence or absence. of a gastric or duodenal lesion, this diagnosis was accepted for the purpose of this investigation. Persistent duodenal deformity was accepted as being due to scarring from ulceration.

Gastric ulcers have been divided into two categories. The first category is the classical lesser curve gastric ulcer to the left of the angulus with no other radiological lesion in the stomach or duodenum, and corresponds to type I of Johnson, Rogers, and Wyatt (1964). The second category, which corresponds to types II and III of Johnson et al. (1964), contains all gastric ulcers which are accompanied by any abnormality of the duodenum, and all gastric ulcers to the right of the angulus. The two categories have been separated in this way because types II and III of Johnson et al. (1964) both seem to possess. such features of duodenal ulcer as hypersecretion and association with blood group $\mathbf{O}$.

Cases were included in this series if the barium meal was normal or showed a duodenal or gastric ulcer. Cases were excluded if there was any suspicion of bleeding from other sites, such as epistaxis, haemoptysis, oesophageal varices, hiatus hernia, carcinoma, or lesions of the large bowel. In order to be comparable with the experimental gastric-cell-shedding series, cases were excluded if there had been a previous gastric operation, except suture of a simple perforation, and for the same reason subjects of blood groups $B$ and AB were excluded.

Specimens of saliva and blood were collected from a number of suitable subjects whose barium meal examinations were normal and with duodenal ulceration for determination of the $\mathrm{ABO}$ blood group and salivary ABH secretor status.

SUBJECTS WITH DUODENAL ULCER The second series was compiled by scrutinizing again 802 available case records from a group of 1,540 subjects with duodenal ulcer, blood grouped and secretor tested by this Department. From the information on pain, obstruction, bleeding, perforation, and operation, subjects were placed into one of five 
clinical categories similar to those used by Langman and Doll (1965), and detailed in the key to Table II.

CONTROLS Two control series were used. The controls for blood group were derived from the same locality as the two series of patients and were blood donors in Liverpoool and south-west Lancashire. The controls for secretor character were normal people in Liverpool (some of whom may have a duodenal ulcer) whose saliva had been tested for secretor character; these secretor controls may not have been representative of the blood group distribution of the locality as they included not only blood donors but also hospital staff, students, and Territorial Army personnel. However, it is known that the secretor polymorphism is much less liable to geographical variation than is the ABO blood group polymorphism.
SECRETOR TESTING Saliva was tested in the usual manner for $\mathrm{H}, \mathrm{A}$, and $\mathrm{B}$ activity (Evans, McConnell, and Donohoe, 1964).

RED CELL GROUPING A tube technique was used (Lawler and Lawler, 1957), and was carried out within 24 hours of collecting the blood sample.

\section{RESULTS}

Table I shows the basic information obtained from subjects ascertained for bleeding in whom the barium meal examinations were either normal or showed evidence of duodenal and gastric ulceration. Table II shows subjects ascertained for duodenal ulcer and

\section{TABLE I}

SUBJECTS ASCERTAINED FOR BLEEDING

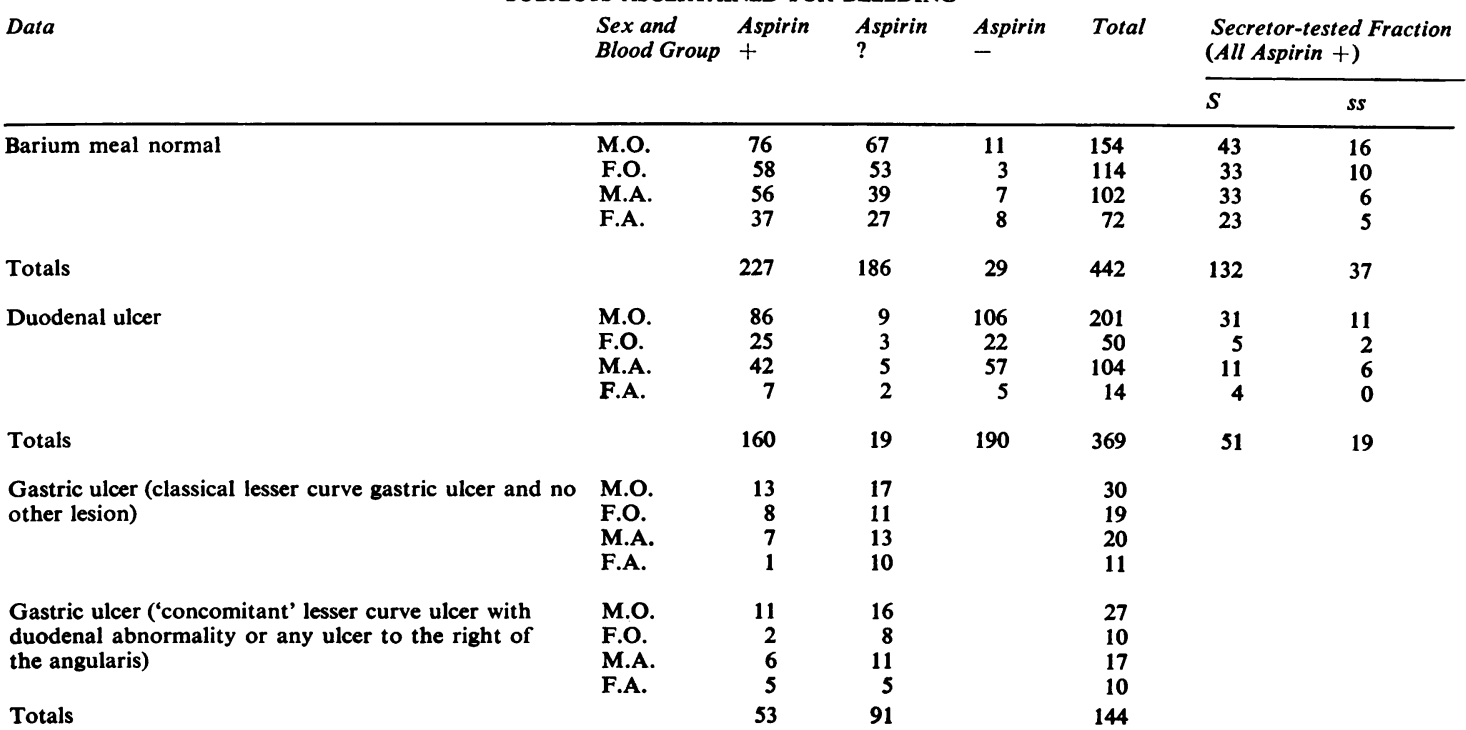

TABLE Ia STATISTICAL COMPARISON BETWEEN GROUPS ASCERTAINED FOR BLEEDING AND NORMAL CONTROLS

Barium meal normal

Comparison between blood groups $\mathbf{O}$ and $\mathbf{A}$

1 Aspirin + v. Aspirin? v. Aspirin-

2 Male $v$. female

$3 \mathrm{O}$ as $\%$ of $\mathrm{O}+\mathrm{A} \quad 60.6$

Secretor data

4 Non-secretors: $21.9 \%$

Duodenal ulcer

Comparison between groups $\mathbf{O}$ and $\mathbf{A}$

5 Aspirin + v. Aspirin? v. Aspirin-

6 Male $v$. female

7 Total barium meal normal $v$. total duodenal ulcers

8 Total barium meal normal $v$. Departmental controls

-

Total duodenal ulcers $v$. Departmental controls

$10 \mathrm{O}$ as $\%$ of $\mathrm{O}+\mathrm{A}=\mathbf{6 8 . 0}$

Secretor data

11 Non-secretors $27 \cdot 1 \%$

Comparison between secretors and non-secretors

12 Barium meal normal $v$. duodenal ulcer (both groups ascertained for bleeding) 
subsequently divided into the five clinical categories. Table III gives details of the control series.

COMPARISON BETWEEN GROUPS ASCERTAINED FOR BLEEDING AND NORMAL CONTROLS After eliminating the non-significant effects of aspirin status and sex, there was a higher incidence of group $\mathbf{O}$ in duodenal ulcer subjects than in bleeders with normal barium meal examinations (Table Ia, 7) and also in duodenal ulcer subjects than in the normal controls (Table Ia, 9). Similarly, bleeders with normal barium meals were higher in group $\mathbf{O}$ than normal controls (Table Ia, 8).

SUBJECTS ASCERTAINED FOR DUODENAL ULCER The two clinical categories for bleeding duodenal ulcer (II and IV, Table II) have been combined and the incidence of group $\mathbf{O}$ compared with that found in

TABLE II

Phenotype Clinical Category ${ }^{1}$ SUBJECTS ASCERTAINED FOR DUODENAL ULCER

\begin{tabular}{|c|c|c|c|c|c|c|c|c|c|c|c|c|c|c|c|c|}
\hline & & & & & & & & & & & & & & & \\
\hline & & \multicolumn{3}{|l|}{$I a$} & \multicolumn{3}{|l|}{$I b$} & \multicolumn{3}{|l|}{ II } & \multicolumn{3}{|l|}{ III } & \multicolumn{3}{|l|}{$I V$} \\
\hline & & $\boldsymbol{M}$ & $F$ & Total & $\boldsymbol{M}$ & $\boldsymbol{F}$ & Total & $\boldsymbol{M}$ & $\boldsymbol{F}$ & Total & $M$ & $\boldsymbol{F}$ & Total & $M$ & $F$ & Total \\
\hline $\begin{array}{l}\mathbf{O} \\
\mathbf{O}\end{array}$ & $\begin{array}{r}\text { S } \\
\text { ss }\end{array}$ & $\begin{array}{l}64 \\
42\end{array}$ & $\begin{array}{l}13 \\
14\end{array}$ & $\begin{array}{l}77 \\
56\end{array}$ & $\begin{array}{l}90 \\
45\end{array}$ & $\begin{array}{l}7 \\
3\end{array}$ & $\begin{array}{l}97 \\
48\end{array}$ & $\begin{array}{l}38 \\
17\end{array}$ & $\begin{array}{l}8 \\
5\end{array}$ & $\begin{array}{l}46(9)^{1} \\
22(6)\end{array}$ & $\begin{array}{l}50 \\
18\end{array}$ & $\begin{array}{l}3 \\
2\end{array}$ & $\begin{array}{l}53(52) \\
20(20)\end{array}$ & $\begin{array}{l}4 \\
3\end{array}$ & $\begin{array}{l}2 \\
1\end{array}$ & $\begin{array}{l}6(6) \\
4(4)\end{array}$ \\
\hline $\begin{array}{l}\mathbf{A} \\
\mathbf{A}\end{array}$ & $\underset{\text { ss }}{\text { S }}$ & $\begin{array}{l}50 \\
22\end{array}$ & $\begin{array}{l}19 \\
13\end{array}$ & $\begin{array}{l}69 \\
53\end{array}$ & $\begin{array}{l}63 \\
33\end{array}$ & $\begin{array}{l}3 \\
6\end{array}$ & $\begin{array}{l}66 \\
39\end{array}$ & $\begin{array}{l}17 \\
11\end{array}$ & $\begin{array}{l}1 \\
3\end{array}$ & $\begin{array}{l}18(2) \\
14(2)\end{array}$ & $\begin{array}{l}22 \\
10\end{array}$ & $\begin{array}{l}1 \\
2\end{array}$ & $\begin{array}{l}23(23) \\
12(12)\end{array}$ & $\begin{array}{l}2 \\
4\end{array}$ & $\overline{1}$ & $\begin{array}{l}2 \text { (2) } \\
5(4)\end{array}$ \\
\hline $\begin{array}{l}\text { B } \\
\text { B }\end{array}$ & $\begin{array}{r}\text { S } \\
\text { ss }\end{array}$ & $\begin{array}{r}14 \\
7\end{array}$ & $\begin{array}{l}4 \\
1\end{array}$ & $\begin{array}{r}18 \\
8\end{array}$ & $\begin{array}{r}11 \\
6\end{array}$ & $\begin{array}{l}4 \\
1\end{array}$ & $\begin{array}{r}15 \\
7\end{array}$ & $\begin{array}{l}3 \\
1\end{array}$ & $\begin{array}{l}1 \\
-\end{array}$ & $\begin{array}{l}4(1) \\
1(1)\end{array}$ & $\begin{array}{l}5 \\
5\end{array}$ & $\frac{2}{-}$ & $\begin{array}{ll}7 & (7) \\
5 & (5)\end{array}$ & $\overline{1}$ & - & $\overline{1}(1)$ \\
\hline $\begin{array}{l}\text { AB } \\
\text { AB }\end{array}$ & $\begin{array}{r}\text { S } \\
\text { ss }\end{array}$ & $\begin{array}{l}3 \\
2\end{array}$ & $\begin{array}{l}2 \\
1\end{array}$ & $\begin{array}{l}5 \\
3\end{array}$ & $\begin{array}{l}2 \\
3\end{array}$ & $\begin{array}{l}1 \\
0\end{array}$ & $\begin{array}{l}3 \\
3\end{array}$ & $\begin{array}{l}4 \\
-\end{array}$ & - & $\begin{array}{l}4(1) \\
-\end{array}$ & $\begin{array}{l}4 \\
1\end{array}$ & - & $\begin{array}{ll}4 & (4) \\
1 & (1)\end{array}$ & 1 & $=$ & $1(1)$ \\
\hline \multicolumn{2}{|c|}{ Totals } & 204 & 67 & 271 & 253 & 25 & 278 & 91 & 18 & $109(22)$ & 115 & 10 & $125(124)$ & 15 & 4 & $19(18)$ \\
\hline
\end{tabular}

${ }^{2}$ No. of patients treated with operation in brackets.

TABLE IIa

STATISTICAL COMPARISONS IN SUBJECTS ASCERTAINED FOR DUODENAL ULCER

Comparisons

Between group $O$ and remaining groups

I Ia $v$. Ib $v$. II $v$. III $v$. IV

2 II $v$. IV

3 Bleeders (II + IV) $v$. non-bleeders (Ia, Ib, III)

4 Uncomplicated duodenal ulcer (Ia) $v$. bleeders (II + IV)

Between groups $O$ and $A$

5 Bleeders $v$. non-bleeders

6 Uncomplicated duodenal ulcer $v$. Departmental controls

$7 \mathrm{O}$ as $\%$ of $\mathrm{O}+\mathrm{A}$ : Uncomplicated duodenal ulcer Bleeding duodenal ulcer (II + IV)

Comparison between secretors and non-secretors

8 Operated $v$. not operated

9 Category Ia v. Ib

\section{$6 \cdot 54$}

0.647

$3 \cdot 28$

$5 \cdot 22$

$2 \cdot 28$

0.011

56.6

$66 \cdot 7$ d.f.

$\begin{array}{ll}4 & >0.10 \\ 1 & >0.10 \\ 1 & >0.05 \\ 1 & <0.05 \\ & \\ 1 & >0.10 \\ 1 & >0.10\end{array}$

$0 \cdot 27$

0.45

${ }^{1}$ Ia = Pain only, no operation

Ib = Pain or obstruction, with operation

II = Bleeding with or without operation

III = Perforation

IV $=$ Perforation and bleeding

TABLE III

CONTROL POPULATIONS

ABO Polymorphism

ABO Blood Group Controls for Liverpool and S.W. Lancashire (Supplied by Nuffield Blood Group Centre)

\begin{tabular}{llllll}
\hline$O$ & $A$ & $B$ & $A B$ & Total & \\
\hline 3,146 & 2,648 & 546 & 170 & 6,510
\end{tabular}

Secretor Polymorphism

Normal People in Liverpool Saliva Tested for Secretor Character

\begin{tabular}{lccc}
\hline Sex & Secretor & Non-secretor & Total \\
\hline Male & 1,081 & 335 & 1,416 \\
Female & 764 & 255 & 1,019 \\
Total & 1,845 & 590 & 2,435
\end{tabular}


uncomplicated duodenal ulcer (clinical category Ia, Table II); this comparison proved to be significant (Table II, 4). However, this significance was not maintained when the bleeding categories II and IV were compared with all the non-bleeding categories combined (Table II, 3).

COMBINATION OF DATA FROM BOTH SERIES The total number of duodenal ulcer subjects who had bled in both series was 486 , and this category proved to be significantly higher in group $O$ than the 595 duodenal ulcer subjects who had not bled (Table IV).

The category of duodenal ulcer subjects who had not bled showed an incidence of group $\mathrm{O}$ much closer to (but significantly different from) that of the normal controls, whereas bleeders with a normal barium meal showed an incidence for group $\mathbf{O}$ intermediate between the two duodenal ulcer categories (Table IV).

\section{TABLE IV}

BLOOD GROUPS IN VARIOUS CLINICAL CATEGORIES AND A CONTROL POPULATION

\begin{tabular}{lllll} 
Blood Group & $\begin{array}{l}\text { Control } \\
\text { Population }\end{array}$ & $\begin{array}{l}\text { Non-bleeding } \\
\text { Duodenal } \\
\text { Ulcer }\end{array}$ & $\begin{array}{l}\text { Bleeding and } \\
\text { Normal } \\
\text { Barium Meal }\end{array}$ & $\begin{array}{l}\text { Bleeding } \\
\text { Duodenal }\end{array}$ \\
\hline Ulcer
\end{tabular}

Comparison between groups $O$ and $A$

Bleeding duodenal ulcer $v$, non-bleeding duodenal ulcer

$x^{2}=8.29 ;$ d.f. $=1 ; p<0.01$

Bleeding with normal barium meal $v$. controls

$x^{2}=6.65 ;$ d.f. $=1 ; \mathrm{p}<0.01$

Non-bleeding duodenal ulcer $v$. controls

$x^{2}=4.80 ;$ d.f. $=1 ; p<0.05$

ASPIRIN STATUS There was a slightly higher incidence of group $\mathrm{O}$ in subjects bleeding following aspirin ingestion where the barium meal examination was normal (Table I, 1), though not to a significant level. There was no recognizable trend due to aspirin in the duodenal ulcer patients (Table $I, 5$ ).

SEX There was no significant interaction between blood group and sex in the patients with normal barium meals (Table I, 2) or in the duodenal ulcer patients (Table I, 6). The latter, however, show a tendency for the number of males of group $O$ and females of group A to be low compared with females of group $\mathrm{O}$ and males of group A respectively.

SECRETION There was a higher percentage of nonsecretors in the duodenal ulcer bleeders (Table I, 11) than in the bleeders with normal results from barium meals (Table I, 4), but not to a significant level (Table I, 12). There was no interaction between blood group and secretion, or between blood group and sex, in either the subjects with normal barium meals or bleeders from duodenal ulcer.

GASTRIC ULCER The number of subjects with gastric ulcer was small and showed no significant departure in blood group distribution from the control population.

\section{DISCUSSION}

It is clear from previous studies by Hurst and Lintott (1939), Muir and Cossar (1955, 1959), and Alvarez and Summerskill (1958) that aspirin ingestion increases the risk of gastric haemorrhage both in subjects with peptic ulcer and those without ulcer. Croft (1963) demonstrated that aspirin frequently caused the gastric mucosa to lose large numbers of mucosal cells, and subsequently Horwich and Evans (1966) showed that an aspirin solution seemed to enhance the pattern of cell shedding which occurred when the mucosa was subjected to a wash of physiological saline. The absence of any significant influence by aspirin ingestion on the blood group distribution in series of subjects without duodenal ulcer and those with ulcers who have suffered gastric haemorrhage suggests that aspirin as such does not increase the risk of bleeding more selectively in subjects of one blood group phenotype than another.

Langman and Doll (1965) showed that there was an increased risk of bleeding in subjects of group $O$ with duodenal ulcer. This finding is confirmed by the present work. Furthermore, the significantly higher incidence of group $\mathbf{O}$ in subjects with bleeding duodenal ulcer than in those with uncomplicated duodenal ulcer suggests that the inclusion of subjects with 'bleeding' (or potentially 'bleeding') duodenal ulcer may be entirely responsible for the high incidence of group $\mathbf{O}$ observed in this disorder. On the other hand, in our rather small series of 125 cases of perforation there was also a high incidence of group $O$, and the relationship may be with the severity of the ulcer as well as with bleeding. The very high incidence of group $\mathrm{O}$ in cases of stomal ulcer (Doll, Swynnerton, and Newell, 1960) is also in favour of there being a relationship between group $O$ and severity of ulcer. The association of group $O$ with bleeding is unlikely to be due to selection, since there was a closely similar incidence of group $\mathbf{O}$ in subjects bleeding from duodenal ulcer of two separate series, one of which was ascertained for the presence of bleeding and the other for the presence of duodenal ulcer. There were no cases common to the two series, which were collected separately and mostly from different hospitals. 
The finding of an increase in blood group $\mathbf{O}$ in subjects who had bled but had had a normal barium meal, to a significant level, may be due to the inclusion of a small number of subjects in whom a duodenal ulcer had been missed radiologically. Alternatively, a number of duodenal ulcers may have healed during the period of up to two weeks which elapsed before the barium meal was done. It is also possible that some subjects have a gastric mucosa which is especially liable to haemorrhage and that these subjects are more frequently of blood group $\mathbf{O}$.

It may be that the inheritance of a gastric mucosa liable to erosion and hence haemorrhage is separate from the inheritance of duodenal ulcer, and if so the acquisition of both would lead to a particularly high risk of gastric haemorrhage. In favour of this concept is an increasing percentage of group $\mathbf{O}$ subjects (as percentage of $\mathrm{O}+\mathrm{A}$ ) from controls to bleeding duodenal ulcer subjects (Table IV). A bleeding propensity conferred by blood group $\mathrm{O}$ (as compared with $\mathrm{A}$ ) may be due to superimposing on a susceptible mucosa the added factors of a high pepsinogen secretion which is itself related to blood group O (Hanley, 1964) and a high acid secretion which is usually present in duodenal ulcer subjects (Cox, 1952).

There was no evidence in the present material of an effect of non-secretion on the incidence of haemorrhage and this is in agreement with the finding of Langman and Doll (1965), though the absence of a relationship to operative treatment in the present study is contrary to their findings (Table II, 8 and 9).

There was no significant interaction between blood group and sex in subjects with duodenal ulcer or normal barium meals (Table I, 2 and 6), and therefore these clinical observations failed to mirror the pattern of gastric mucosal cell shedding observed by Horwich and Evans (1966). It may be of interest to note that despite this lack of statistical significance there was a tendency for males of group $\mathbf{O}$ and females of group A to be rather infrequent in relation to the other two phenotypes in subjects bleeding from duodenal ulcer. It may be, therefore, that the phenotypes in which large numbers of cells are shed in the experiment, viz., male $\mathrm{O}$ and female $\mathrm{A}$, may be to some extent protected against gastric bleeding, notwithstanding the fact that in general subjects with bleeding duodenal ulcer include a high percentage of persons of group $\mathbf{O}$.

There was no suggestion of an interaction between blood group and secretor status related to gastric haemorrhage in this series. Croft (1966) has suggested that shedding of gastric cells may be an important factor in occult minor bleeding from aspirin ingestion, but that other factors play dominant roles in determining the occurrence of major haemorrhage.
This may explain the disparity between the results of the previous aspirin cell shedding experiments (Horwich and Evans, 1966) and the series of patients with major haemorrhages reported here.

\section{SUMMARY}

The distribution of blood groups $\mathrm{O}$ and $\mathrm{A}$ has been investigated in two series of subjects, one series ascertained because of upper gastrointestinal bleeding and the other because of duodenal ulcer. Information on significant aspirin ingestion was obtained about subjects in the first series, which was then divided into those with duodenal ulcer, gastric ulcer, and normal, according to the subsequent barium meal examination. The second series was divided into five clinical categories which included bleeding. Comparisons of the blood group distributions were made within and between the series and with normal controls.

There was a significant increase of group $O$ in subjects with bleeding duodenal ulcer over the normal controls, and a significant increase of group $O$ in the patients with bleeding duodenal ulcers over those with duodenal ulcers which had not bled up to the time of ascertainment. Those who bled but had a normal barium meal examination had a significantly higher incidence of blood group $\mathbf{O}$ than was found in the control population.

There was no evidence that aspirin ingestion influenced the distribution of blood groups significantly in the subjects with duodenal ulcer or normal barium meals. No significant interaction was demonstrable either between blood group and secretion, or between blood group and sex in the subjects with duodenal ulcer or normal barium meals.

These findings are discussed, and it is concluded that the present work confirms the increased risk of bleeding in subjects of group $\mathrm{O}$ reported by Langman and Doll (1965). Furthermore the present work suggests that the inclusion of subjects with bleeding duodenal ulcer may be entirely responsible for the high incidence of blood group $\mathrm{O}$ in reported series of duodenal ulcer. On the other hand, in our rather small series of 125 patients with perforation there was also a high incidence of group $\mathrm{O}$, and the relationship may be with severity of ulcer as well as with bleeding.

We wish to thank the Nuffield Foundation and the Medical Research Committee of the United Liverpool Hospitals for generous financial support; Professor C. A. Clarke, Professor P. M. Sheppard, F.R.S., Dr. D. Lehane and Dr. M. J. S. Langman for much helpful advice; also Miss M. F. Bullen, S.R.N., and Mrs. N. Maddocks, S.R.N., for contacting patients and collecting specimens; Miss Diane Townsend and Miss Heather Millington for performing the saliva tests; Mrs. B. Rothwell for 
secretarial assistance; the records officers and their staffs in many Liverpool hospitals for their cooperation; and medical colleagues at many Liverpool hospitals and family doctors for allowing us to contact patients under their care.

\section{REFERENCES}

Aird, I., Bentall, H. H., Mehigan, J. A., and Roberts, J. A. F. (1954). The blood groups in relation to peptic ulceration and carcinoma of colon, rectum, breast, and bronchus. An association between the ABO blood groups and peptic ulceration. Brit. med. J., 2, 315-321.

Alvarez, A. S., and Summerskill, W. H. J. (1958). Gastrointestinal haemorrhage and salicylates. Lancet, 2, 920-925.

Boyd, W. C., and Shapleigh, E. (1954). Separation of individuals of any blood group into secretors and nonsecretors by use of a plant agglutinin (lectin). Blood, 9, 1195-1198.

Clarke, C. A., Cowan, W. K., Edwards, J. W., Howel-Evans, A. W., McConnell, R. B., Woodrow, J. C., and Sheppard, P. M. (1955) The relationship of the ABO blood groups to duodenal and gastric ulceration. Brit. med. J., 2, 643-646.

, Edwards, J. W., Haddock, D. R. W., Howel-Evans, A. W., McConnell, R. B., and Sheppard, P. M. (1956). ABO blood groups and secretor character in duodenal ulcer: population and sibship studies. Brit. med. J., 2, 725-731.

- Evans, D. A. P., McConnell, R. B., and Sheppard, P. M. (1959). Secretion of blood group antigens and peptic ulcer. Brit. med. $J ., 1,603-607$.

Cox, A. J., Jr. (1952). Stomach size and its relation to chronic peptic ulcer. Arch. Path., 54, 407-422.
Croft, D. N. (1963). Aspirin and the exfoliation of gastric epithelial cells. Cytological and biochemical observations. Brit. med. J., 2, 897-901.

- (1966). The action of analgesic substances on the gastric mucosa. In Symposium on The Toxicity of Analgesic Substances. J. Pharm. Pharmacol, 18, 354-361

Doll, R., Swynnerton, B. F., and Newell, A. C. (1960). Observations on blood group distribution in peptic ulcer and gastric cancer. Gut, 1, 31-35.

Evans, D. A. P., McConnell, R. B., and Donohoe, W. T. A. (1964). Fucose and agglutinogen contents of urine from patients with duodenal ulcers. J. Lab. clin. Med., 64, 581-593.

Hanley, W. B. (1964). Hereditary aspects of duodenal ulceration: serum-pepsinogen level in relation to ABO blood groups and salivary ABH secretor status. Brit. med. J., 1, 936-940.

Horwich, L., and Evans, D. A. P. (1966). The influence of the ABO blood group and salivary ABH secretor status on the cell removing effect of aspirin on human gastric mucosa. Gut, 7, 525-530.

Hurst, A., and Lintott, G. A. M. (1939). Aspirin as a cause of haematemesis: a clinical and gastroscopic study. Guy's Hosp. Rep., 89, 173-176.

Johnson, H. D., Love, A. H. G., Rogers, N. C., and Wyatt, A. P. (1964). Gastric ulcers, blood groups and acid secretion. Gut, 5 , 402-411.

Langman, M. J. S., and Doll, R. (1965). ABO blood group and secretor status in relation to clinical characteristics of peptic ulcers. Gut, 6, 270-274.

Lawler, S. D., and Lawler, L. J. (1957). Human Blood Groups and Inheritance, 2nd ed. Heinemann, London.

Muir, A., and Cossar, I. A. (1955). Aspirin and ulcer. Brit. med. J., 2, 7-12. 541. 